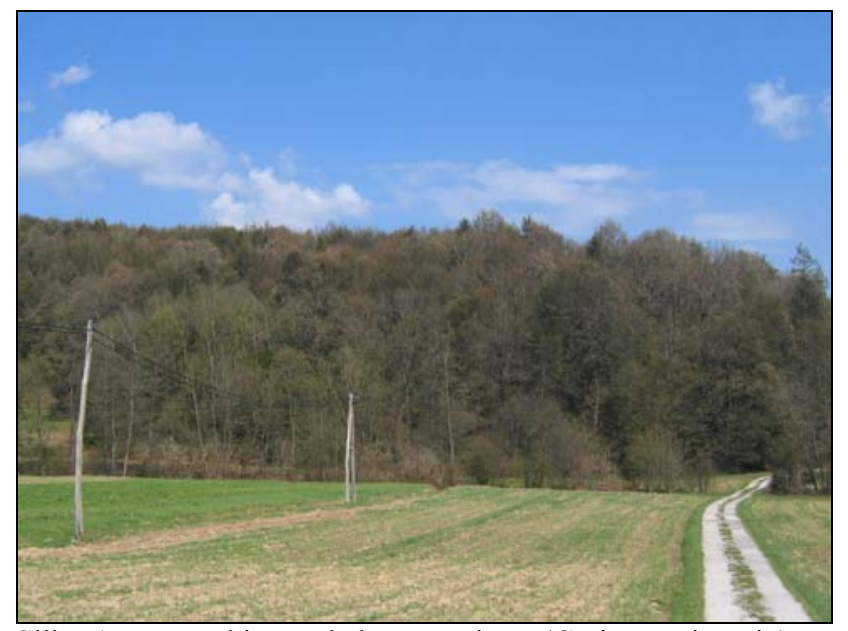

Slika 1: »Jesenski« pogled na gozdove (Grajena pri Ptuju) po neurju - foto avgust 2008

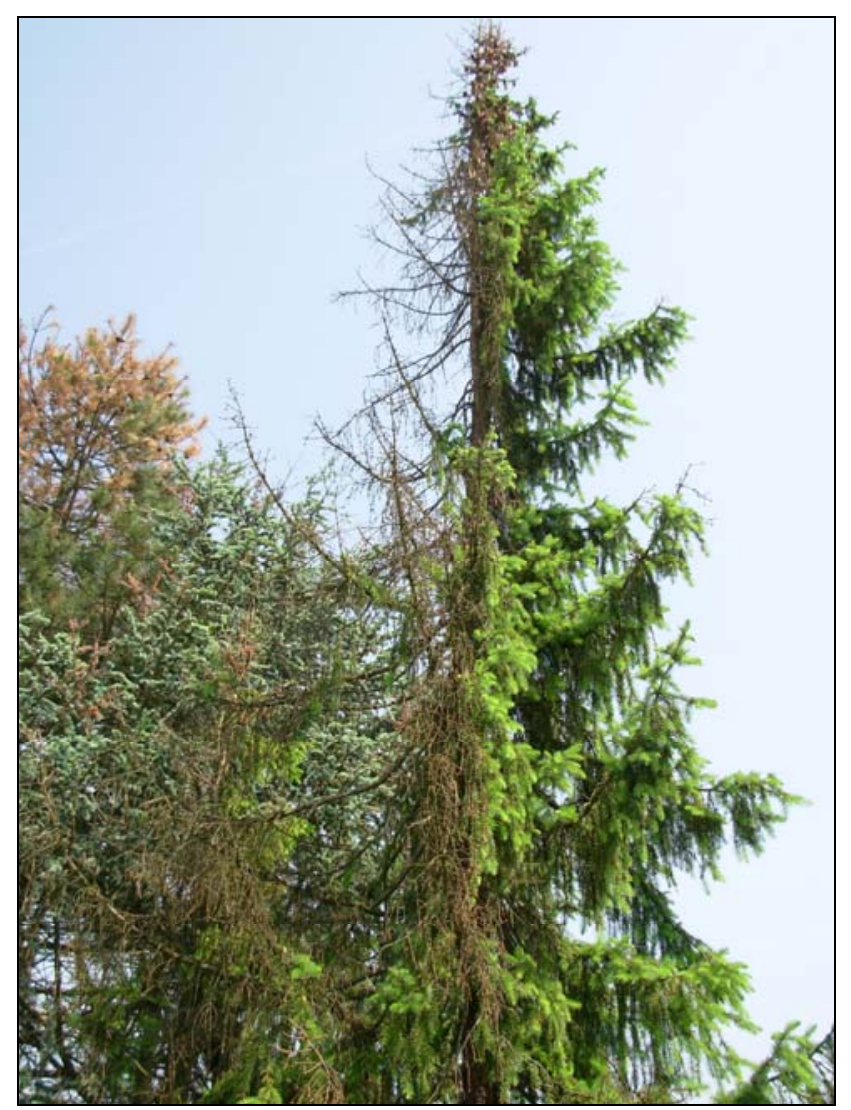

Slika 3: Poškodbe na drevju zunaj gozda (Grajena pri Ptuju) foto maj 2009

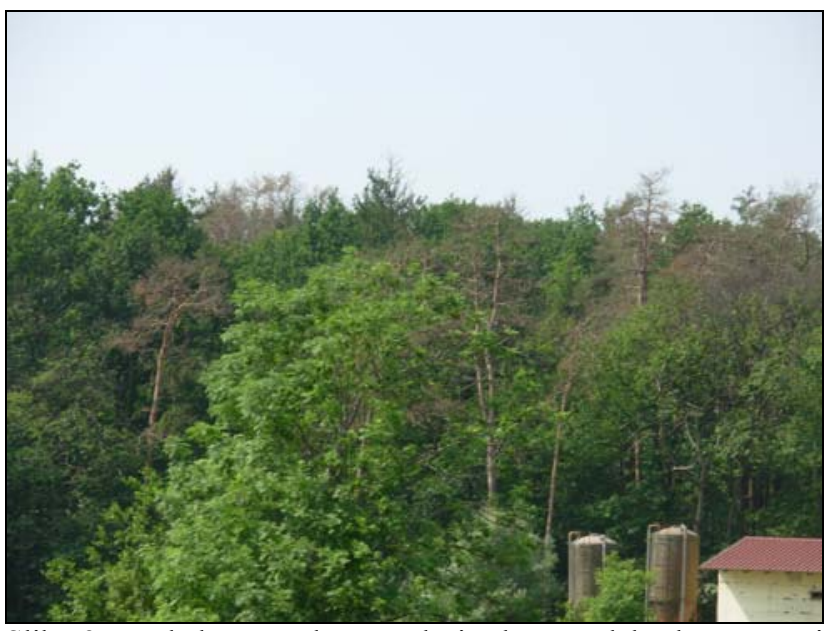

Slika 2: Pogled na gozdove $\mathrm{z}$ rdečim borom slabo leto po toči (Grajena pri Ptuju) - foto maj 2009

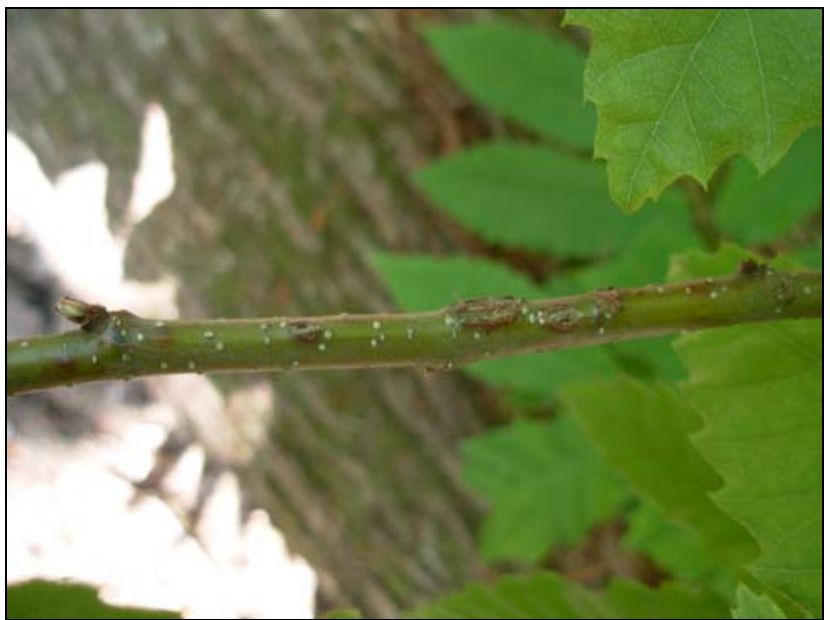

Slika 4: Poškodbe na kostanjevem poganjku - foto maj 2009

\title{
Posledice snegoloma decembra 2008 v Gozdnogospodarskem območju Bled
}

\section{Vida PAPLER-LAMPE*, Marija KOLŠEK}

Težak in obilen sneg je $\mathrm{v}$ drugi polovici decembra 2008 v Gozdnogospodarskem območju Bled poškodoval 49.000 bto $\mathrm{m}^{3}$ lesne mase na okoli 5.000 ha gozdov. Težišče snegoloma je bilo $\mathrm{v}$ nadmorskih višinah $1.000-1.300 \mathrm{~m}$ na planotah Pokljuke in Mežaklje.
Ogromne količine mokrega snega, ki je padal od 1. do 20. decembra 2008, so povzročile posamične in šopaste poškodbe pretežno čistih smrekovih sestojev v razvojni fazi drogovnjaka in debeljaka. Tipi poškodb so bili prelomi, cepljenja debel, podrtice posamičnih 
dreves in šopov ter poškodbe vrhov ter delov krošenj. Lomljenje je bilo postopno, začelo se je po 15 . decembru, trajalo pa je skoraj en mesec.

V najbolj prizadetih delih gozdov je pozimi ležala dva do tri metre debela snežna odeja. Sneg se je stopil šele konec maja. Sistematičen pregled terenov v maju je pokazal, da je prizadetih precej več gozdov, kot smo sprva predvidevali.

Najbolj poškodovano območje je planota Pokljuke, predvsem destabilizirani sestoji, ki jih je prizadel že snegolom lata 2007. Snegolom leta 2008 je imel središče delovanja okoli 100 m višje kot tisti v letu 2007. Snegolom je v manjši meri prizadel tudi pretežno čiste smrekove sestoje na Mežakli (zgornji del), Jelovici (Martinček) in Karavankah (Belca). Najbolj prizadeta razvojna faza so drogovnjaki.

Predvsem pa so neugodne dodatne poškodbe v drogovnjakih, ki jih je zelo močno prizadel že snegolom

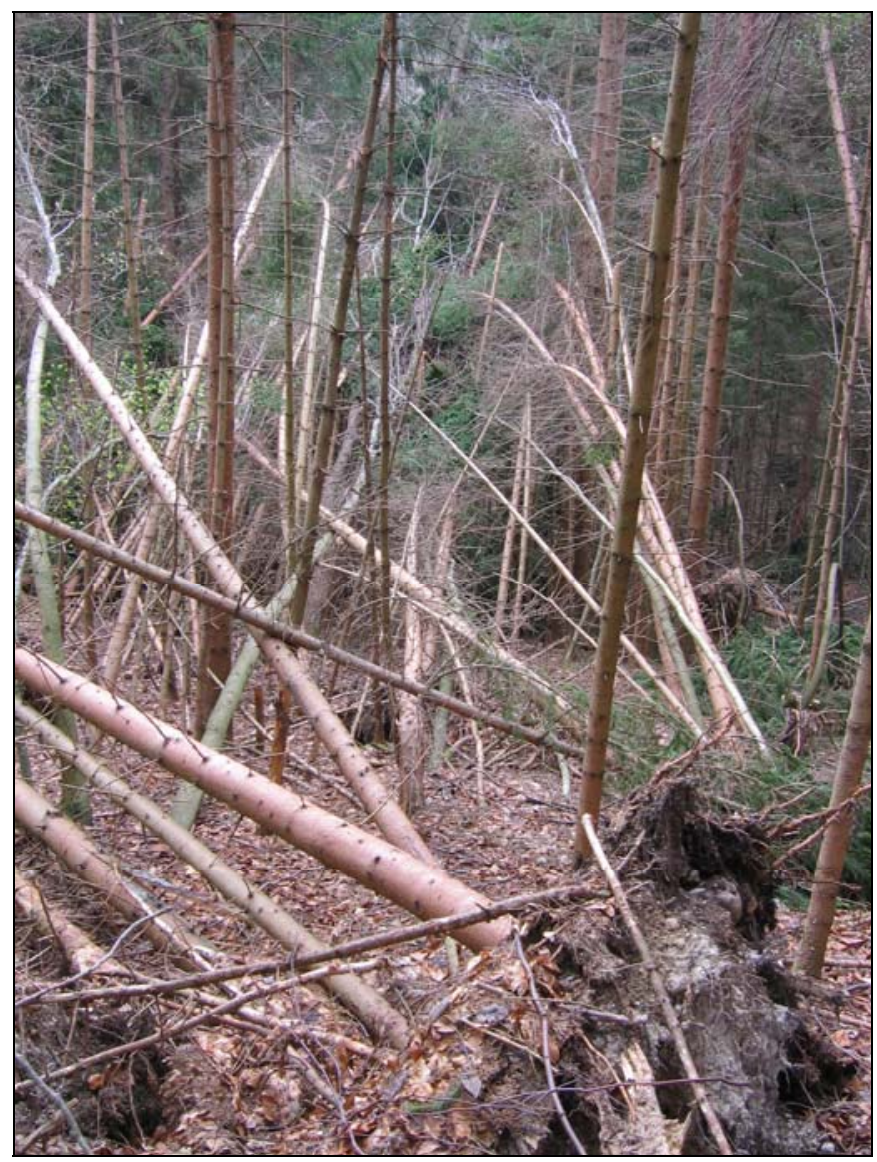

Slika 1: Posledice snegoloma v smrekovem drogovnjaku lata 2007. Sestojna zasnova in sklep sta se še poslabšala. Napad smrekovih lubadarjev na poškodovana drevesa je zelo močan, ker sta na poškodovanem območju zaradi pogostih naravnih ujm v zadnjih letih namnožena osmerozobi smrekov lubadar (Ips typographus) in šesterozobi smrekov lubadar (Pityogenes chalcographus).

\section{Viri}

Papler-Lampe V. 2009. Načrt sanacije gozdov poškodovanih v snegolomu decembra 2008. Zavod za gozdove Slovenije, Območna enota Bled

Zavod za gozdove Slovenije, Večna pot 2, 1000 Ljubljana *vida.papler-lampe@zgs.gov.si

\section{Namnožil se je bukov rilčkar skakač - Rhynchaenus fagi}

\section{Maja JURC $^{1 *}$, Marija KOLŠEK ${ }^{2}$}

V letu 2009 ugotavljamo namnožitev bukovega rilčkarja skakača (Rhynchaenus fagi). To je majhen, približno 2-3 mm dolg temno rjav hrošček $\mathrm{z}$ rilčkom, ki odskoči ob vsaki nevarnosti. Prisoten je povsod v Slo- veniji. Največ poškodb je povzročil na Gorenjskem in v osrednji ter jugovzhodni Sloveniji, kje so se zaradi njegove namnožitve $\mathrm{v}$ mesecu maju bukovi gozdovi ponekod jesensko obarvali. Pogosteje se pojavlja na 